\title{
Pengaruh Seleksi dan Pelatihan terhadap Prestasi Kerja Karyawan pada PT. Adimulia Palmo Lestari di Desa Peninjauan
}

\author{
Ratna, Rts. Hartha Delima \\ Sekolah Tinggi Ilmu Ekonomi Graha-Karya Muara Bulian Jambi
}

\begin{abstract}
The purpose of this study is to explain the effect of selection and training on employee performance at PT. Adimulia Palmo Lestari in the village of Peninjauan. The analytical method used is quantitative using multiple linear regression analysis tools. Testing the significance of the influence of selection variables (X1) and training (X2) as independent variables and employee performance $(Y)$ as the dependent variable carried out $t$ test and $F$ test. The results of testing the hypothesis on the effect of selection variables on employee performance that the t count is 3.560> from the t table 1.667 and the significance number is (sig) $0.001<$ from the level of significance ( $\alpha$ ) 0.05 (5\%), thus it can be known that selection has an influence on employee performance. The results of testing the hypothesis of the effect of training variables on employee performance that the $t$ count is 2.089> from the t table 1.667 and the significance number is (sig) $0.004<$ from the level of significance ( $\alpha$ ) 0.05 (5\%), thus it can be known that training has an influence on employee performance. The results of testing the hypothesis of the selection and training variables on employee performance shows that the $F$ value obtained $F$ count 15.956 with a significance level of $(0.000$ $<0.05)$, the value of $F$ table of 3.11 means that F count (15.995) > F table (3.11) thus Ho is rejected and Ha is accepted, meaning that selection (X1) and training (X2) have a positive effect simultaneously or together on the work performance of employees of $P T$. Adimulia Palmo Lestari in the village of Peninjauan. Adjusted R square generated is 0.265 . So it can be concluded that the percentage of the effect of selection and training on employee performance at PT. Adimulia Palmo Lestari amounted to $26.5 \%$ and the remaining $73.5 \%$ was influenced by other variables not examined in this study.
\end{abstract}

Keywords: selection, training, employee performance

\section{PENDAHULUAN}

Seleksi karyawan merupakan salah satu bagian yang penting dalam keseluruhan proses Manajemen Sumber Daya Manusia. Dikatakan demikian, karena apakah dalam organisasi terdapat sekelompok karyawan yang memenuhi tuntutan organisasional / tidak sangat tergantung pada cermat tidaknya seleksi yang dilakukan.

Menurut Wahyudi (2010:82) Seleksi tenaga kerja diartikan sebagai suatu proses pemilihan beberapa orang dari sekelompok orang-orang dengan preferensi tertentu. Tujuan dari seleksi itu sendiri yakni untuk mendapatkan karyawan yang terampil dan memiliki keahlian sesuai dengan kebutuhan serta skor tertinggi dalam penilaian atau pertimbangan lainnya.

Proses seleksi yang efektif harus dilakukan dengan mempertimbangkan informasi tentang analisis pekerjaan, karena dalam analisis pekerjaan itu tergambar uraian pekerjaan yang akan dilakukan. Berbagai persyaratan yang harus dipenuhi oleh para karyawan yang melakukan pekerjaan tersebut dan standar produktivitas kerja yang harus dicapai. Jadi seleksi yang efektif dan penempatan karyawan yang tepat akan mendorong naiknya prestasi kerja karyawan.

Pelatihan merupakan suatu proses mengubah perilaku karyawan yang sistematis dalam suatu kerangka tujuan untuk meningkatkan sasaran organisasi (lvacevich dalam Ismanto, 2014:44). Pelatihan bagi karyawan merupakan suatu proses mengajarkan pengetahuan dan keahlian tertentu serta sikap agar karyawan semakin trampil dan mampu melaksanakan tanggung jawabnya dengan semakin baik, sesuai dengan standar yang diharapkan perusahaan (Mangkuprawira, 2008:135).
Program pelatihan yang efektif dapat menigkatkan kinerja. keterampilan, sikap/moral dan potensi organisasi (Gomez, 2011). Untuk melihat efektifitas program pelatihan maka perusahaan perlu melakukan penilaian terhadap perubahan sikap dan keterampilan. Selain itu. penyelenggaraan pelalihan diharapkan dapat mendukung karir karyawan yang dapat dicapai selama masa tugasnya. Penyelenggaraan program pelatihan harus mempunyai berbagai manfaat bagi pengembangan karir jangka panjang yang membantu karyawan untuk menerima tugas dan tanggung jawab yang lebih besar di waktu yang akan datang.

Sementara, Gomez (2011) mengemukakan bahwa pemahaman tentang prestasi kerja tidak bisa dilepaskan dari pemahaman yang bersifat multidimensional. Kemauan dan kemampuan yang dimiliki seseorang dalam melakukan pekerjaan dapat terlihat dari prestasi kerjanya, dalam usaha penerapan konsep, gagasan, ide dengan efektif dan efisien sehingga tercapai tujuan yang ditetapkan oleh perusahaan. Kemampuan ini bukan hanya pada kemampuan mengelola, tetapi memimpin dan mengaplikasikan semua kemampuan yang ada dalam dirinya untuk mencapai tujuan yang telah ditetapkan bersama dalam suatu unit perusahaan.

Berdasarkan latar belakang penelitian, maka sebagai masalah penelitian yang akan di teliti adalah: 1) Bagaimana seleksi karyawan pada PT. Adimulia Palmo Lestari. 2) Bagaimana pelatihan karyawan pada PT. Adimulia Palmo Lestari. 3) Bagaimana prestasi kerja karyawan pada PT. Adimulia Palmo Lestari. 4) Bagaimana pengaruh seleksi dan pelatihan terhadap 
pretasi kerja karyawan pada PT. Adimulia Palmo Lestari.

Adapun tujuan dari penelitian ini adalah : 1) Untuk mengetahui kondisi seleksi karyawan pada PT. Adimulia Palmo Lestari. 2) Untuk mengetahui kondisi pelatihan karyawan pada PT. Adimulia Palmo Lestari. 3) Untuk mengetahui kondisi prestasi kerja karyawan pada PT. Adimulia Palmo Lestari. 4) Untuk mengetahui pengaruh seleksi dan pelatihan terhadap pretasi kerja karyawan pada PT. Adimulia Palmo Lestari.

\section{Tinjauan Pustaka \\ Seleksi}

Menurut Simamora (2011), seleksi merupakan proses pemilihan dari sekelompok pelamar yang paling memenuhi kriteria seleksi untuk posisi yang tersedia di dalam perusahaan. Ada tiga hal yang menyebabkan seleksi menjadi hal yang penting, yaitu:

1. Kinerja seorang manajer tergantung pada sebagian kinerja bawahannya.

2. Seleksi yang efektif penting karena biaya perekrutan yang dikeluarkan oleh perusahaan dalam pengangkatan pegawai tidak sedikit.

3. Seleksi yang baik itu penting karena implikasi hukum dari pelaksanaannya secara serampangan.

\section{Pelatihan}

Menurut Alwi (2011:217) pelatihan adalah suatu proses kegiatan yang terarah pada peningkatan kemampuan dan keahlian Sumber Daya Manusia organisasi yang berkaitan dengan jabatan atau fungsi yang menjadi tanggung jawab individu yang bersangkutan saat ini. Efektifitas program pelatihan adalah suatu istilah untuk memastikan apakah program pelatihan dijalankan dengan efektif dalam mencapai sasaran yang ditentukan.

\section{Prestasi Kerja}

Penilaian prestasi kerja adalah suatu proses yang bertujuan untuk mengetahui atau memahami tingkat kinerja karyawan dibandingkan dengan tingkat kinerja karyawan lainnya atau dibandingkan dengan standar yang telah ditetapkan. Standar kinerja adalah tingkat yang diharapkan dari kinerja (Subekti dkk, 2012:71).

Tujuan penilaian prestasi kerja adalah memperbaiki dan meningkatkan prestasi kerja karyawan yang pada akhirnya nanti akan bermanfaat bagi pelaksanaan fungsi-fungsi operasional SDM yang lain seperti seleksi, pengembangan, kompensasi, pemeliharaan dan pemutusan hubungan kerja (Panggabean dalam Subekti, 2012:72).

\section{METODE PENELITIAN}

Jenis penelitian yang digunakan dalam penelitian ini termasuk dalam kategori penelitian asosiatif kausal dengan menggunakan pendekatan kuantitatif. Penelitian asosiatif kausal adalah penelitian yang bertujuan untuk mengetahui pengaruh antara dua variabel atau lebih. Penelitian ini akan menjelaskan hubungan mempengaruhi dan dipengaruhi dari variabel-variabel yang akan diteliti, yaitu pengaruh variabel seleksi dan pelatihan terhadap variabel prestasi kerja karyawan.

Alat Analisis Data yang di peroleh dari angket atau ceklis, dijumlahkan sesuai dengan bentuk instrumen yang digunakan( arikunto,2013:282).

\section{Skala Likert}

Pengisian kuesioner diukur dengan menggunakan skala likert yang terdiri atas: sangat setuju, setuju, netral, tidak setuju, sangat tidak setuju. Kelima penilaian tersebut diberi bobot sebagai berikut :

1. Jawaban sangat setuju diberi bobot 5

2. Jawaban setuju diberi bobot 4

3. Jawaban netral diberi bobot 3

4. Jawaban tidak setuju diberi bobot 2

5. Jawaban sangat tidak setuju diberi bobot 1

Skala likert kemudian menskala individu yang bersangkutan dengan menambahkan bobot dari jawaban yang dipilih. Nilai rata-rata dari masing-masing responden dapat dikelompokkan dalam kelas interval, dengan jumlah kelas intervalnya dapat dihitung dengan rumus sebagai berikut (Arikunto, 2010:163):

Interval $=$ nilai tertinggi - nilai terendah

$$
\begin{aligned}
& \text { Jumlah kelas } \\
& 5-1
\end{aligned}
$$

Interval $=\frac{}{5}$

Interval $=0,8$ (nol koma delapan)

Interval tersebut kemudian dimasukkan kedalam rentang skala distribusi jawaban responden sebagaimana tabel berikut:

Tabel 1. Rentang Skala Interval

\begin{tabular}{cc}
\hline Rentang Skala & Penggolongan \\
\hline $1,01<\mathrm{x} \leq 1,80$ & Sangat Tidak Baik \\
$1,81<\mathrm{x} \leq 2,60$ & Tidak Baik \\
$2,61<\mathrm{x} \leq 3,40$ & Cukup Baik \\
$3,41<\mathrm{x} \leq 4,20$ & Baik \\
$4,21<\mathrm{x} \leq 5,00$ & Sangat Baik \\
\hline
\end{tabular}

Sumber: Arikunto, 2010

1. Uji Validitas \& Reliabilitas

a. Uji Validitas, untuk mengetahui valid tidaknya suatu kuesioner

b. Uji Realibilitas, untuk mengukur konsistensi kuesioner yang merupakan indikator dari variabel

2. Analisis Regresi Linear Berganda, untuk meneliti pengarub beberapa variabel independen(variabel $\mathrm{x}$ ) terhadap variabel dependen (variabel y) dengan,

$\mathrm{Y}=\mathrm{a}+\mathrm{b}_{1} \mathrm{X}_{1}+\mathrm{b}_{2} \mathrm{X}_{2}$

Dimana:

$\mathrm{Y}=$ Prestasi Kerja Karyawan

$\mathrm{a}=$ Bilangan Konstanta 
$\mathrm{b}_{1} \quad=$ Koefisien regresi seleksi

$\mathrm{b}_{2}=$ Koefisien regresi pelatihan

$\mathrm{X}_{1}=$ Seleksi

$\mathrm{X}_{2}=$ Pelatihan

3. Uji t (Uji Parsial), digunakan mengetahui apakah variabel independen secara parsial mempunyai pengaruh yang signifikan terhadap variabel dependen.

4. Uji F (Uji Serempak), digunakan untuk menguji tingkat signifikan koefisien regresi variabel independen secara serempak terhadap variabel dependen.

5. Uji Koefisien Determinasi $\left(\mathrm{R}^{2}\right)$,digunakan untuk mengetahui berapa persen variasi variabel dependen dapat dijelaskan oleh variasi variabel independen.

\section{HASIL DAN PEMBAHASAN}

Hasil penelitian dan pembahsan merupakan jawaban dari tujuan penelitian sebagai berikut: pengaruh seleksi dan pelatihan terhadap prestasi kerja karyawan adalah untuk menjelaskan pengaruh seleksi dan pelatihan terhadap prestasi kerja karyawan

Metode analisis yang digunakan adalah kuantitatif yang menggunakan alat analisis regresi linear berganda. Pengujian signifikansi pengaruh variabel seleksi $\left(\mathrm{X}_{1}\right)$ dan pelatihan $\left(\mathrm{X}_{2}\right)$ sebagai variabel independen dan prestasi kerja karyawan (Y) sebagai variabel dependen dilakukan uji $\mathrm{t}$ dan uji $\mathrm{F}$. Persamaan regresi adalah $\mathrm{Y}=$ $15,509+0,270 \mathrm{X} 1+0,146 \mathrm{X} 2$ artinya nilai konstanta 15,509 jika ke-3 variabel bebas bernilai 0

Dari persamaan tersebut dapat ditarik kesimpulan bahwa:

1. Jika terdapat seleksi karyawan $\left(\mathrm{X}_{1}\right)$ dan pelatihan karyawan $\left(\mathrm{X}_{2}\right)$, maka prestasi kerja karyawan $(\mathrm{Y})=$ 15,509 .

2. Jika kondisi seleksi karyawan $\left(X_{1}\right)$ naik satu satuan, maka prestasi kerja karyawan (Y) naik sebesar 0,270. Dengan asumsi kondisi pelatihan karyawan $\left(\mathrm{X}_{2}\right)=0$.

3. Jika kondisi pelatihan karyawan $\left(\mathrm{X}_{2}\right)$ naik satu satuan, maka prestasi kerja karyawan (Y) naik sebesar 0,146. Dengan asumsi kondisi seleksi karyawan $\left(\mathrm{X}_{1}\right)=0$.

Hasil pengujian hipotesis atas pengaruh variabel seleksi terhadap prestasi kerja karyawan bahwa nilai $\mathrm{t}_{\text {hitung }}$ adalah sebesar 3,560 > dari angka $\mathrm{t}_{\text {tabel }} 1,667$ dan angka signifikansi sebesar (sig) $0,001<$ dari level of signifikansi $(\alpha)$ 0,05 (5\%), dengan demikian dapat diketahui bahwa seleksi mempunyai pengaruh terhadap prestasi kerja karyawan.

Hasil pengujian hipotesis atas pengaruh variabel pelatihan terhadap prestasi kerja karyawan bahwa nilai $t_{\text {hitung }}$ adalah sebesar 2,089 > dari angka $t_{\text {tabel }} 1,667$ dan angka signifikansi sebesar (sig) $0,004<$ dari level of signifikansi $(\alpha)$ 0,05 (5\%), dengan demikian dapat diketahui bahwa pelatihan mempunyai pengaruh terhadap prestasi kerja karyawan.
Hasil pengujian hipotesis atas variabel seleksi dan pelatihan terhadap prestasi kerja karyawan menunjukan bahwa nilai $F$ diperoleh $F_{\text {hitung }} 15,956$ dengan tingkat signifikansi sebesar $(0,000<0,05)$, nilai $\mathrm{F}_{\text {tabel }}$ sebesar 3,11 ini berati bahwa $\mathrm{F}_{\text {hitung }}(15,956)>\mathrm{F}_{\text {tabel }}(3,11)$ dengan demikian Ho ditolak dan Ha diterima, artinya bahwa seleksi $\left(\mathrm{X}_{1}\right)$ dan pelatihan $\left(\mathrm{X}_{2}\right)$ berpengaruh positif secara simultan atau bersama-sama terhadap prestasi kerja karyawan PT. Adimulia Palmo Lestari di desa Peninjauan. Adjusted $R$ square yang dihasilkan sebesar 0.265. Jadi dapat disimpulkan persentase pengaruh seleksi dan pelatihan terhadap prestasi kerja karyawan pada PT. Adimulia Palmo Lestari sebesar $26,5 \%$ dan sisanya $73,5 \%$ dipengaruhi variabel lain yang tidak diteliti dalam penelitian ini.

\section{SIMPULAN}

pengaruh seleksi dan pelatihan terhadap prestasi kerja karyawan adalah untuk menjelaskan pengaruh seleksi dan pelatihan terhadap prestasi kerja karyawan.

Metode analisis yang digunakan adalah kuantitatif yang menggunakan alat analisis regresi linear berganda. Pengujian signifikansi pengaruh variabel seleksi $\left(\mathrm{X}_{1}\right)$ dan pelatihan $\left(\mathrm{X}_{2}\right)$ sebagai variabel independen dan prestasi kerja karyawan (Y) sebagai variabel dependen dilakukan uji $\mathrm{t}$ dan uji $\mathrm{F}$. Persamaan regresi adalah $\mathrm{Y}=$ $15,509+0,270 \mathrm{X} 1+0,146 \mathrm{X} 2$ artinya nilai konstanta 15,509 jika ke-3 variabel bebas bernilai 0 , variabel seleksi terhadap prestasi kerja karyawan bahwa nilai $t_{\text {hitung }}$ adalah sebesar 3,560 > dari angka $t_{\text {tabel }}$ 1,667 dan angka signifikansi sebesar (sig) 0,001 < dari level of signifikansi $(\alpha) 0,05(5 \%)$, pengaruh variabel pelatihan terhadap prestasi kerja karyawan bahwa nilai thitung adalah sebesar 2,089 > dari angka $t_{\text {tabel }}$ 1,667 dan angka signifikansi sebesar (sig) $0,004<$ dari level of signifikansi $(\alpha)$ 0,05 (5\%), hipotesis atas variabel seleksi dan pelatihan terhadap prestasi kerja karyawan menunjukan bahwa nilai $\mathrm{F}$ diperoleh $\mathrm{F}_{\text {hitung }} 15,956$ dengan tingkat signifikansi sebesar $(0,000<0,05)$, nilai $F_{\text {tabel }}$ sebesar 3,11 ini berati bahwa $F_{\text {hitung }}(15,956)>F_{\text {tabel }}$ $(3,11)$ dengan demikian Ho ditolak dan Ha diterima, artinya bahwa seleksi $\left(\mathrm{X}_{1}\right)$ dan pelatihan $\left(\mathrm{X}_{2}\right)$ berpengaruh positif secara simultan atau bersama-sama terhadap prestasi kerja karyawan PT. Adimulia Palmo Lestari di desa Peninjauan. Adjusted $R$ square yang dihasilkan sebesar 0.265. Jadi dapat disimpulkan persentase pengaruh seleksi dan pelatihan terhadap prestasi kerja karyawan pada PT. Adimulia Palmo Lestari sebesar 26,5\% dan sisanya 73,5\%

\section{DAFTAR PUSTAKA}

Alwi, Syafaruddin. 2012. Manajemen Sumber Daya Manusia Strategi Keunggulan Kompetitif. Yogyakarta: BPFE

Arep, Ishak. 2013. Manajemen Sumber Daya Manusia. Edisi Kedua, Yogyakarta. BPEC 
Arikunto, Suharsimi. 2010. Manajemen Penelitian. Jakarta : Rineka Cipta

Ghozali, Imam. 2011. Apkikasi Analisis Multivariate dengan Program IBM SPSS. Edisi 5. Semarang : Badan Penerbitan Universitas Diponegoro

Gomez-Mejia, Luis R and David B. Balkin and Robert L. Cardy. 2012. Managing Human Resources. Prentice Hall: Pearson Education, Inc

Hamalik, Oemar. 2010. Pendidikan Guru Berdasarkan Pendekatan Kompetensi. Jakarta: Bumi Aksara

Hasibuan, Malayu SP. 2010. Manajemen Sumber Daya Manusia. Jakarta: Bumi Aksara

Ismanto, Setyobudi. 2014. Konsumen dan Pelayanan Prima. Malang: Gaya Media

Mangkunegara, Anwar Prabu. 2014. Manajemen Sumber Daya Manusia Perusahaan. Bandung: Remaja Rosdakarya

Mangkuprawira, Sjafri. 2008. Bisnis, Manajemen, dan SDM. Bogor: IPB Press 